УАK 323.1

ББК 66.094

DOI 10.22394/1682-2358-2017-3-19-24

T.A. Nikitina, Candidate of Sciences (Politics), Docent of the General Legal Disciplines and Political Science Department, Orenburg State University

I.A. Terentieva, Candidate of Sciences (Pedagogies), Docent of the General Legal Disciplines and Political Science Department, Orenburg State University

\section{NATIONALISM \\ IN THE CONTEXT OF POLITICAL ANALYSIS}

The causes, essence and prospects of nationalism in multi-ethnic Russia are analyzed. The main manifestations of national contradictions in socio-political life in the former soviet countries are considered. The authors conclude that the growth of ethnic consciousness of Russians, which serves as a replacement of state ideology, is a negative result of the process of building a nation state where the public policy conforms to corporate interests.

Key words and word-combinations: nationalism, ideology, politics, political process.
T.А. Никитина, кандидат политических наук, дочент кафедрь обиих правовьхх дисчиплин и политологи Оренбургского государственного yниверситета (email: nikitina4145@mail.ru)

И.А. ТерентьеВа, кандидат педагогических наук, дочент кафедрьг общих правовьгх дисциплин и политологии Оренбургского государственного универсuтета (email: irina_m1973@mail.ru)

\section{НАЦИОНААИЗМ B KOHTEKCTE ПОАИТОАОГИЧЕСКОГО АНА ИЗА}

Аннотация. Анализируются причины возникновения, сущность и тенденции развития национализма в полиэтничной России. Рассмотрены основные проявления национальных противоречий в общественно-политической жизни, сложившиеся на постсоветском пространстве. Делается вывод о том, что рост этнического самосознания русских, выступающего в качестве замены государственной идеологии, является негативным результатом процесса строительства государства-нации и подчинения государственной политики корпоративным интересам.

Ключевые слова и словосочетания: национализм, идеология, политика, политический процесс.

$$
\mathrm{H}
$$
связи с чем исследование феномена национализма в политической науке приобретает особую актуальность. Активность национамистических процессов особенно прояв яется у народов, находящихся на начамьной стадии соџиамьного и политического разви- 
тия. Приспособление к глобальной цивилизации часто воспринимается ими как кумьтурная и экономическая экспансия развитых сосеАних государств. Похожая ситуация сложкилась и на постсоветском пространстве. На рубеже веков прекратияа свое существование сложившаяся система ценностей и начала зарождаться совершенно новая, что неизбежно ведет к возникновению чувства незащищенности у множества мюдей. Ранее понятная и четко спланированная жизнь в обществе потеряла определенность, и человек сталкивается с проблемой поиска новых ориентиров. В таких условиях возрастает потребность снова обрести устойчивую социально-политическую идентичность и психологический комфорт, что в итоге проявцяется в форме национализма [1, с. 7].

Оџенивая данный феномен с этической точки зрения, многие исследователи вынуждены признать его огромную историческую роль в проџессе становления и развития наций и государств [2, с. 210]. Отмечено, что на протяжении последних двух столетий национализм оказал существенное влияние на процесс консолидации во Франции, объединения - в Италии и Германии, восстановления политической независимости - в Польше, Финляндии и Греции. Тот же путь прошли бывшие советские республики. Вместе с тем именно национализм разрушил такие величайшие мировые империи, как Британская, Османская и Российская. Аанный феномен стал мощным инструментом создания диктаторских режимов в Германии, Италии и Испании, а в переплетении с расизмом и фашизмом нанес огромный урон различным народам [3, с. 89] .

Поиску причин, определению сущности наџионализма посвящено множество исследований, однако загадка его до сих пор не разрешена. Национальные идеи неизбежно порождают различные политические акции, которые в системе и представцяют собой национацизм. В самом общем виде наџионализм можно рассматривать в качестве политического Авижения, направленного на защиту интересов национацьной общности в международном масштабе и в процессе взаимодействия с государственной властью [4, с. 123]. При этом национализм может быть идеологией как основой государствообразующей нации, так и этнического меньшинства.

Многие национальные Авижения сосредоточены на использовании политических инструментов Аля усиления консолидации гражАан одной нации и защиты их интересов как внутри страны, так и на международном уровне. Национализм в политической сфере наиболее эффективен тогда, когда страна нуждается в культурной и соџиально-политической сплоченности всего общества ици отдельных групп. Практика показывает, что Аанное явление используется с целью утвердить не только факт наличия нации и ее интересов, но и превосходство национальных потребностей наА всеми иными замыслами общества. Высочайшая оценка национальных приоритетов часто смешивается с идеями самостоятельности, в итоге это ведет к потребности обретения части государственного суверенитета и его политического закрепиения. Формируется представцение нации об автономии в рамках государства или о необходимости создать собственное. Целью национализма может быть повышение эффективности деятельности государства, реформирование, подъем уровня культуры 
и соџиальной защищенности наџии [5, с. 23]. Аостаточно распространенной целью национальных движений является обретение национальными группами «культурной автономии», гарантирующей гражданам опредеменной национальности особые возможности выражения идентичности, расширение прав на особые формы политического представительства. Учитывая значение наџиональных движений в современном мире, заинтересованными политическими акторами национализм используется в качестве прикрытия при завоевании власти абсолютно иными соџиальными сиками. Такое проявмение наџионацизма часто становится мишь орудием внедрения на политический рынок акторов, не заинтересованных в огласке своих подиинных цемей.

Каковы же причины возникновения национализма? Часть исследователей полагает, что данный феномен есть идеология и политика, которые используют в своих целях национальные чувства. Существует огромное количество классификаций форм национализма. Опредеменный интерес представляет классификация, предложенная $\Lambda$. Снайдером и Аж. Хейсом [5, с. 206]. $\Lambda$. Снайдер выдемяет четыре типа наџионализма:

- интегрирующий национализм (1845-1871) представмял собой силу, которая способствовала объединению народов Италии и Германии в период феодальной раздробленности;

- разъединяющий нащионализм (1871-1890) характеризуется борьбой за национальную независимость народов, входивших в состав Османской, Австро-Венгерской и Аругих империй, которые в результате распались;

- агрессивный национализм (1900-1945) - это пример острого конфмикта разцичных национальных интересов, которые проявились в двух мировых войнах. Такой вид наџионализма идентичен империализму. Современный национализм (после 1945 г.) проявцяется в основном в антиколониальных революциях и распространяется в глобальном масштабе.

Аж. Хейс представляет следующую кмассификацию национализма: якобинский, традиџионный, интегральный, экономический и киберальный. Наиболее расширенная классификация представлена российским политологом и геопокитиком Э.А. Поздняковым:

- наџионализм этнический характерен для угнетенных и порабошенных народов, ведущих борьбу за нащиональное освобождение и стремящихся обрести собственную государственность. Ему присуща определенная идеология и политика;

- национализм державно-государственный проявмяется у государственно оформленных наций, которые пытаются воплотить в жизнь свои национальные интересы;

- бытовой национализм - это реализация националистических чувств в малых соџиальных группах, на межкичностном уровне. Ему сопутствует ксенофобия и враждебное отношение к Аругим этническим группам [6, с. 143] .

ОАнако представленные примеры типологий ничего не объясняют, а Аишь подтверждают, что наџионализм - это политика и идеология, манипулирующая национальными чувствами дмя решения своих задач. Следовательно, национализм есть не что иное, как единство идеологии и политики. В отсутствие 
мюбого из названных элементов останется привязанность к народу, преданность родине - этнические категории, которые обладают истинной силой. Но если приобщить определенного рода идеологию и политику, то возникает национамизм, создающий и разрушающий государства, объединяющий и раздемяющий, а при определенных обстоятельствах разжигающий конфликты и ненависть.

Национализм может проявцяться в виде патриотизма и в виде агрессивного противостояния Аругой нации, ее Аискриминации. Это напрямую зависит от содержания политической илеологии государства. Особенность данного феномена в том, что он всегда воспринимался исследователями неоднозначно. Представители марксистского направления в политологии выдемяли именно положительные черты национализма угнетенных народов колониальных стран. Парамлельно буржкуазный национализм воспринимался как нечто отрицательное.

В России современный национализм также воспринимается неоднозначно. ОАни осуждают его Аеструктивную идеологию, Аругие подАерживают, причем в самой агрессивной форме (например, скинхеды). В российском обществе проблемы национализма на рубежке XX-XXI вв. приобрели особую актуальность и остроту. Каковы же истоки распространения идеологии национацизма в конце ХХ в. в государстве, которое активно боролось с ним, с самым крайним его проявлением - фашизмом?

Необходимо учитывать, что Россия - многонациональное государство, на ее территории проживает более ста тридцати народов, поэтому национальные проблемы проявцялись с определенным постоянством. В начале 1990-х годов национальные конфликты в России обострицись. Причинами Аанной ситуации стали снижение уровня жизни большинства граждан, усиление миграџии, конфронтация межАу различными наџиями и культурами, война в Чеченской республике и терроризм [7, с. 23]. Какова соџиально-психологическая основа проявления националистических настроений?

Бесспорно, одним из его наиболее массовых носителей явцяется мюмпенизированная страта общества. К. Маркс видец в мюмпен-пролетариате «накипь всех классов» - социальный слой, который не имеет устойчивой социальной позиции. Националистические идеи притягивают мюмпенов, так как дают им возможность

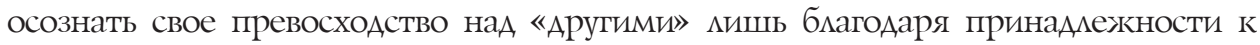
определенной национальной группе. Не нужно трудиться, прикладывать усилия или проявцять талант, чтобы ощущать себя выше узбека, грузина или татарина только потому, что ты русский. И^и воспринимать себя выше русского, потому что ты еврей, армянин и т.А. Национализм разделяет нации [8, с. 236] .

В советский периоА, с одной стороны, активно, культивировалась идея «Аружбы народов», а с Аругой - сохранялась почва Аля матентного напряжения межэтнических взаимоотношений. Соответственно, формально все гармонировало с официальной идеологией - интернационацизмом, но как только в начале перестройки ослаб контроль, национацьные проблемы стали резко обостряться. В период застоя в национацьном вопросе наблюдался Ауализм, расхождение межАу реацьными процессами и их идеологическим «облачением». От общества многое скрывацось - реальные настроения, напряженность и конфмикты. Научное, объективное изучение наџиональных отношений было 
под запретом. В СССР официально национальный вопрос считался разрешенным. После распада Советского Союза углубились противоречия, и национализм вырос во всех бывших республиках.

В процессе обретения суверенитета вновь возникшие государства нужАались в идеологическом подтверждении мегитимности своей власти, наиболее приемлемой оказалась идеология национализма. Россия из могучей сверхдержавы превратилась в экономически неконкурентное государство. По многим показателям она потеряла свои позиџии, стала страной без прошиого и будущего. Новейшая российская история подверглась ревизии, пересмотру, а деятельность нескольких поколений советских граждан была перечеркнута. В постсоветский период 25 млн русских мюдей оказались в сопредельных государствах, уже чужих Аля них. Их начали притеснять, изгонять и подвергать дискриминации по национальному признаку. Народ претерпел серьезное национальное унижение [9, с. 27]. Аанная ситуация - не почва ми Амя возрождения национацизма?

Парадокс заключается в том, что Россия, веками собиравшая вокруг себя земии и создавшая могучее государство, теперь выступает главным инициатором развала, объявив о суверенитете и о приоритете своих норм права союзным. Нарушилась долговременная историческая традиция, а последующие события содействоваци росту в стране национализма. Развац Союза сыграц на руку сепаратистам. Аля них национацизм был знаменем в борьбе за политическую власть. В закавказских и среднеазиатских республиках национализм разрастался с особым размахом. На Украине, особенно в ее западной части, вспыхнула волна антирусского национализма [10, с. 102] .

Президент России В.В. Путин 16 апреля 2015 г. во время прямой минии так охарактеризовац описанную ситуацию: «Что произошло? Произошло то, что АюАи устали от нищеты, от воровства, от хамства властей, от их неуемной жадности, от коррупџии, от олигархов, забравшихся во власть. Аюди устаци от этого. А когда общество и страна скатываются в такое состояние, то Аюди начинают искать выходы из этой ситуации и, к сожалению, частично обращаются к тем, кто, спекулируя на текущих трудностях, предлагает какие-то простые решения. Среди них националисты. А что, у нас этого не было, что $\Lambda и$, в 90-х годах? Не было вот этого “парада суверенитетов", не было национализма, вспыхнувшего тогда ярким цветом? Аа все это было, мы все прохоАили! И так везде происходит на самом деле. Вот это произошио в Украине. Поэтому это не наш провац, это провац внутри самой Украины» [11] .

Разрастание и проникновение национализма в Россию создает огромную политическую угрозу стабильности государства, поэтому необходимо создать ему препятствия. Путь обособления, национальной замкнутости, преАложенный национацистами, не убережет Россию от опасностей. Нынешняя политическая власть видит эту угрозу и противостоит ей. «Что касается радикацьного национализма, то мы всегда с ним боролись, и будем бороться, - отметил В.В. Путин. - Я неоднократно говориц о том, что национацизм - вредное и разрушительное явцение Аля целостности Российского государства, потому что оно изначально скмадывалось как многонационацьная и многоконфессионацьная страна» [11]. 
Сегодня в мире наблюдаются проџессы интернационализации, порождаемые развитием мирового рынка, науки, техническим прогрессом и информатизацией общества. Аанные процессы неминуемы, и препятствовать им бессмысленно. ОАнако они порождают в обществе противоречия, так как происходит столкновение традиџий национальных культур, которые, в свою очередь, сглаживают национальные различия и создают новые условия национального подъема. Современный национализм стремится сдерживать процессы интеграции и интернаџионализаџии [6], но это путь тупиковый, наџионалистические установки не способствуют поиску раџиональных способов разрешения возникающих трудностей. Мировой опыт подтверждает, что представители разных наџиональностей могут жить в согласии, если одна нация не возвышается наА Аругими, если язык и культура развиваются свободно. Важно, как относятся Аруг к Аругу сами народы. Что преобладает в их чувствах и сознании - толерантность, доброта или вражАа, неприязнь и ненависть к Аругой нации. Негатив в отношениях вспыхивает быстро, а искореняется медменно, поэтому особое значение имеет последовательная наџиональная политика, ориентированная на мирное решение проблем и противоречий, на предотвращение национальных столкновений.

Таким образом, национализм, как правимо, зарождается при низком уровне жизни и глубоком соџиальном расслоении обшества. ИАеология наџионацизма, проникая в размичные страты, содействует возникновению агрессивных молодежных Авижений и политических организаџий наџионалистической направленности. Сегодня угроза дмя демократии, исходящая от радикальных националистических движений, является несущественной. Необходима взвешенная идея национального возрождения России, забота обо всех ее народах на основе принципов демократии, справедмивости и гуманизма, патриотизма и взаимного уважения. В таких условиях национализм в России не возникнет.

\section{Библиографический список}

1. Вдовин А.И. Этнополитика и формирование новой государственности в России // Кентавр. 1994. № 1. С. 3-11.

2. Бройи Дж. Подходы к исследованию национализма // Нации и национализм. М., 2002. C. 201-236.

3. Хейс Карлтон Дж.Х. Национализм. М., 2010.

4. Сидорина Т.Ю. Национализм: теории и политическая история. М., 2006.

5. Дробижева Л.М., Солдатова Г.В., Коротеева В.В. Демократизация и образы национализма в Российской Федерации в 90-е годы. М., 1996.

6. Поздняков Э.А. Нация. Национализм. Национальные интересы. М., 1994.

7. Тишков В.А. Что есть Россия и российский народ // Pro et Contra. 2007. Т. 11, № 3 (37). C. 21-41.

8. Дробижева Л.М. Социальные проблемы межнациональных отношений в постсоветской России. М., 2003.

9. Малахов В.C. «Национальная политика» как феномен политической речи // Понаехали тут... Очерки о национализме, расизме и культурном плюрализме. М., 2007.

10. Малинова О.И. Партийные идеологии в России: атрибут или антураж? // Полис. Политические исследования. 2001. № 5. С. 97-106.

11. Путин: украинский кризис - «это не наш провал». URL: https://regnum.ru/news/ polit/1916006.html 